\title{
On Ideological and Political Education Function of College Campus Culture and Its Implementation Path
}

\author{
Juan Zhang \\ Shandong University of Finance and Economics, Jinan Shandong, 250014, China
}

Keywords: Campus culture, Ideological and political education, Educational function, Implementation path.

\begin{abstract}
College campus culture has multiple ideological and political education functions, mainly reflected in the aspects of orientation, penetration, edification, cohesion, innovation, restraint, mind and body cultivation. Under the background of new era, certain path must be adopted to fully exert ideological and political education function of campus culture, i.e. depend on socialist core value system to guide campus culture construction, improve campus environment, guide students to cultivate good campus spirit and create unique and excellent campus culture.
\end{abstract}

\section{Introduction}

Campus culture as a kind of subculture occupies a very important position in ideology and other fields. It is the foundation for students to carry out ideological and political education. Under the background of new era, giving full play to ideological and political education function of campus culture contributes to creating harmonious campus culture and can well help college students grow.

\section{Ideological and political education function of campus culture}

The main feature of campus culture is campus spirit. It is a kind of basic belief, cultural concept and value embodiment which is created and formed in long-term education process ${ }^{[1]}$. Campus culture has eight functions in terms of ideological and political education.

\subsection{Orientation function}

Campus culture has the guidance function for teachers and students in three aspects. Firstly, value guidance. Students and teachers in colleges and universities deem campus culture as their consistent value and campus spirit, so campus culture plays an indelible role in action mode and spirit level of teachers and students, and guide their values. Secondly, guidance of public opinion. Patriotism and socialism are important components of campus culture. Students and teachers propagandize education concept, important values and behavior standards, and colleges and universities help students establish the awareness of becoming useful persons. Thirdly, goal orientation. College students are guided to unify the goals to the school development objective through holding multiple campus culture activities and drive the course of achieving educational objective.

\subsection{Penetration function}

Generally speaking, certain culture intensively embodies national economy, political concept and ideology. Certain campus culture shows the content of national policies and economy to certain degree. If political and economic culture does not exist in culture, such culture does not exist. So, campus culture reveals political and economic requirements of students and teachers to certain degree. Campus culture activity may be held to penetrate the content of ideological and political education to students and teachers, and let them clearly know the political and economic situation so as to make the activity content consistent with the content of ideological and political education. 


\subsection{Edification function}

Campus culture profoundly influences and educates teachers and students as well as makes them establish their correct thought through campus culture environment, learning atmosphere and rick activities. Diverse cultural activities and fine campus environment can edify and improve aesthetic judgment and taste of teachers and students.

\subsection{Cohesion function}

Campus spirit plays the main cohesion role in campus culture. The essence and soul of campus culture are campus spirit which grasps the final direction and path of campus culture development and specific manifestation pattern, and influences the essence of culture ${ }^{[2]}$. Campus spirit makes most teachers and students own the similar ideas, dreams and habits in the same environment. Such cultural identity has strong cohesive force, makes the thought of students and teachers consistent in a skilful way and makes them become a group with dreams and cohesive force and own sense of belonging and happiness.

\subsection{Restraint function}

Behavior contents and methods of teachers and students are restrained by campus culture, including tangible and intangible forms. The tangible form refers to style of study, rules and teaching style. The behavioral norms of all must conform to institutional requirements. The behaviors conforming to the system must be encouraged and praised. The behaviors which do not conform to provisions will be despised by teachers and students. Campus culture can stop any bad though and action, and make those behaviors become correct actions so that students' morality level can improve. The intangible form refers to campus public opinion. The extensive propaganda and education can make students make a clear distinction between the right and wrong and make campus culture become the important force to constrain bad behaviors of teachers and students.

\subsection{Personality shaping function}

The establishment of dream, belief, morality and hobby by college students cannot be separated from the driving force of campus culture. For example, rigorous campus atmosphere building, positive learning atmosphere construction, friendly, establishment of harmonious and relaxing interpersonal relationship and construction of fair and tolerant collective public opinion facilitate college students to develop firm, diligent, brave and confident psychological traits. Campus culture has the function of cultural value orientation. Campus culture makes approve campus culture in the aspects of thinking mode, ideal, concept, psychological quality and value through creating the good campus environment and humanistic spirit. Then, spirit and temperament of teachers and students can be effectively shaped ${ }^{[3]}$.

\section{Diverse paths to achieve ideological and political education function of campus culture}

Any coin has two sides. Campus culture is of no exception. Campus culture has both positive and negative functions for ideological and political education. The correct culture plays the promotion function. But, unhealthy campus culture will hinder healthy physical and mental development of teachers and students, and cannot obviously embody the effect of ideological and political education. Thus, the function of ideological and political education can be fully exerted through establishing healthy and characteristic campus culture with diverse paths. Finally, the educational function of campus culture can be promoted.

\subsection{To guide campus culture construction with socialist core value system}

One of important contents in socialist culture is campus culture. Ideological and political education function of campus culture can be better embodied only through the guidance of correct method. With continuous development of China's economy and politics (especially global economic development), economic component, employment mode and structure subject show various changes. 
As a result, people's material and spiritual needs, and environmental culture become diversified. Thus, people's values differ a lot. These diversified factors gradually penetrate in campus. Thus, teachers and students judge and choose among multiple values. In such case, many students may feel confused and do not know how to make a choice. we should firmly guide campus culture through socialist core value system.

The fundamental manifestation of China's socialist ideology is socialist core value system and also the theoretical basis for people to struggle for their dreams. To stick to socialist core value system, we must further specify the guiding force of Marxism. In the process of campus culture construction, all kinds of diversified cultures may appear, but the guiding role of Marxism cannot be changed.

\subsection{To improve and optimize campus material environment which can stimulate students and teachers to advance bravely}

Material basis influences the superstructure. Campus material conditions may influence ideological and political education in multiple aspects such as influencing their spiritual pursuit, aesthetics, behavior mode and values. Campus material conditions include campus landmark building, favorable hardware and software conditions, campus environment distribution, activity, training site and sanitation. The good campus material environment can make people advance actively and strive for dreams. Compared with those simple and pure activities, the education effect of campus material environment is more profound and lasting. There are three measures to build the good campus material environment. Firstly, to optimize campus structure and planning layout. In the aspect of campus architecture, the number of campus buildings and aesthetic feeling of campus buildings should be valued to give full play to the functions of campus architecture. It is required to maintain the damaged infrastructure in time, and maintain campus hygienic conditions. Meanwhile, multiple newsstands and broadcasting stations should be set up to speed up propagation of campus culture. Secondly, enhance campus culture facilities construction, establish diversified sites for culture and sports activities and scientific and technological innovation activities, increase the investment and make sure the sites are absolutely safe. Most importantly, it is required to update books and reference materials, expand library construction, and offer more spiritual nourishment. Thirdly, attach importance to and enhance campus information construction. It is required to increase campus hardware investment intensity, establish wired and wireless network and website bases, determine the base of online ideological and political education and give full play to mobile phone network education function and publicity function for campus culture.

\subsection{To improve and optimize campus institutional environment which can standardize thought and behavior of teachers and students}

Institutional environment is a system to dispatch living, production and interest relationship ${ }^{[4]}$. The institution is the result of people's activities, and a system to standardize people's behaviors. There are three measures. Firstly, to improve and optimize campus institution, including school management institution, working system of staffs and institutions students should obey. The behaviors of teachers and students can be better standardized, and they can continuously advance on the correct way only through establishing and perfecting rational institution as well as cultivating favorable learning style and campus atmosphere. It is required to better stimulate working and learning enthusiasm and creativity of teachers and students, further establish harmonious, friendly, civilized and vital campus environment only through optimizing and improving various campus institutions as well as managing students and teachers in a scientific and rational way. Campus institution can become a part of campus culture only when it is accepted by teachers and students. So, it is required to enhance propaganda of campus culture institution, strengthen supervision and management, and establish reward and punishment measures to standardize and simulate activities of teachers and students. 


\subsection{To cultivate and develop campus spirit with era characteristics}

Campus spirit intensively reflects the common value and ideal of teachers and students. It is also the essence and soul of campus culture, and plays a vital role for individual development of both teachers and students. Besides, it rings through their life, and is lasting. (1) Campus spirit is not changeless, and will change with the era changes. So, we should advance with the era, conform to era characteristics, show era characteristics in campus culture and achieve scientific development. (2) Shape the common campus value. The common campus value decides people's thinking method and behavioral attitude, and students' values penetrate in the society. (3) Refine characteristic school motto. School motto has been integrated in the inner heart of teachers and students. The patterns of manifestation include teaching style, learning style and living habits. Campus spirit has strong relevance with school motto. In the practical activity of schools, if school motto is accepted by teachers and students, it will be promoted and expanded infinitely, and further become campus spirit.

\subsection{To create campus culture with distinct characteristics based on moral education}

Campus culture has distinct characteristics, which is also the charm of campus culture. Characteristic campus culture is beneficial for it to achieve its ideological and political education function. Firstly, influence students through excellent humanistic spirit. People's inherent humanistic spirit is more important than the external manifestations, and can help students and teachers establish the ideal. For example, a college invites multiple academicians to give the first lecture to freshmen. These persons have the same nature, that is, they start from the grassroots, firm their belief, be indomitable and finally succeed. This will greatly motivate and influence students. Secondly, edify students with noble culture, and help them establish integrity and moral sense. To be specific, schools may hold the signature activity of person cultivation based on honesty, hold speech contest about examination taking based on honesty, and create the honest atmosphere. Meanwhile, some thanks giving activities may be held. For instance, gift bag for love can be held to make students edified by moral culture. Thirdly, cultivate students with cultural knowledge, enhance education about teacher's ethics and strive to teach by personal examples. For instance, celebrity lecture activity may be held. Fourthly, inspire students with life practice. The activity of arranging outstanding youths enter the campus may be held. Through these activities, students and teachers can realize their fate is closely related to national fate, make efforts and continuously achieve their value.

\section{Conclusion}

Ideological and political education function of campus culture has very important positive significance. But, achieving ideological and political education function of campus culture is a long-term and very complex system project. During promoting ideological and political education function of campus culture, "two systems" should be constructed, and one wrong region should be prevented. Two systems refer to comprehensive organization system dominated by student union, Youth League General Branch and class adviser. It is beneficial for campus culture construction. Secondly, campus spirit evaluation system with the main contents of dream, pursuit, value, personality and morality should be established to ensure the direction of ideological and political education. "Prevention of one wrong region" means to prevent formalism and ignore emotional features of teachers and students in campus culture construction. We should devote ourselves to better creating campus culture through the above paths and achieve ideological and political education function of college campus culture.

\section{References}

[1] Zhang De, Wu Jianping, Campus Culture and Talent Training, Beijing: Tsinghua University Press, 2015.

[2] Tang Min, Realization Mechanism of Ideological and Political Education Function of Campus 
Culture, Journal of Hebei University of Science and Technology (Social Sciences), 2017, (3).

[3] Huang Tengjiao, He Yonghong, On Function of Ideological and Political Education Function in Campus Culture Construction, Journal of Sichuan Normal College (Philosophy and Social Sciences), 2015, (3).

[4] Li Hui, Study on Modern Ideological and Political Education Environment, Guangzhou: Guangdong People's Publishing House, 2016. 